\title{
Vibrio vulnificus infection in Southern Brazil - Case report ${ }^{*}$
}

\author{
Infecção por Vibrio vulnificus no sul do Brasil - Relato de caso
}

\author{
João César Beenke França ${ }^{1}$ \\ Elise Sanfelice ${ }^{3}$ \\ Arthur Gentili ${ }^{5}$
}

\author{
Sonia Mara Raboni \\ Diego Polido ${ }^{4}$ \\ Fabricio Marques ${ }^{5}$
}

\begin{abstract}
The genus Vibrio is a member of the family Vibrionaceae, and among their disease-causing species, Vibrio vulnificus, a lactose-positive gram-negative bacillus, is one of the most virulent pathogen of the noncholerae vibrios. We describe the case of a 39-year-old male patient, who was using immunosuppressive therapy, admitted to the hospital for liver transplantation. Twelve hours later, the patient presented high fever, myalgia, anuria and erythematous plaques on lower limbs, of rapid growth and proximal progression. The patient was treated with ceftriaxone, meropenem and oxacillin, however he expired within 30 hours. Blood cultures showed growth of a gram-negative bacillus, which was later identified as Vibrio vulnificus.
\end{abstract}

Keywords: Immunosuppression; Immunocompromised host; Seafood; Sepsis; Shellfish; Skin diseases

Resumo: O gênero Vibrio é membro da família Vibrionaceae, e entre as espécies patogênicas, Vibrio vulnificus, bacilo gram negativo lactose positivo, tem sido frequentemente citado. Descrevemos o caso de um paciente masculino de 39 anos, em uso de medicação imunossupressora, admitido no hospital para transplante hepático. Doze horas após a internação, o paciente evoluiu com febre, mialgias, anúria e placas eritematosas em membros inferiores, com rápido crescimento e evolução proximal. O paciente foi tratado com ceftriaxona, meropenem e oxacilina sem melhora, evoluindo para óbito em 30 horas. Hemocultura mostrou crescimento de bacilo gram negativo posteriormente identificado como Vibrio vulnificus.

Palavras-chave: Alimentos marinhos; Dermatopatias; Frutos do mar; Hospedeiro imunocomprometido; Imunossupressão; Sepse

\section{CASE REPORT}

A 39-year-old male patient, diagnosed with ulcerative colitis and sclerosing cholangitis 10 years ago, was admitted to the hospital for elective liver transplantation. The patient was taking azathioprine $100 \mathrm{mg} / \mathrm{d}$, ursacol $1.2 \mathrm{~g} / \mathrm{d}$, prednisone $10 \mathrm{mg} / \mathrm{d}$, simvastatin $20 \mathrm{mg} / \mathrm{d}$, spironolactone $100 \mathrm{mg} / \mathrm{d}$, folic acid and calcium carbonate. On admission his general condition was good, and he had a healthy skin tone, was

well hydrated, feverless, jaundiced +++/IV, with stable vital signs. On physical examination, he had target painless hepatomegaly, spider veins and lower limb edema. Twelve hours after admission, the patient had high fever, tachycardia, myalgia in the calves and anuria.

Ceftriaxone was empirically started. Within hours, lesions resembling purplish erythematous

Received on 27.03.2012.

Approved by the Advisory Board and accepted for publication on 10.07.2012.

* Study carried out at the the Teaching Hospital - Federal University of Paraná (Universidade Federal do Paraná - HC-UFPR) - Curitiba (PR), Brazil. Conflict of interest: None

Financial funding: None

Master's Degree - MD of the Infectology Service of the Teaching Hospital - Federal University of Paraná (Universidade Federal do Paraná - HC-UFPR) Curitiba (PR), Brazil.

PhD - MD and Professor of the Department of Infectious Diseases, Teaching Hospital - Federal University of Paraná (Universidade Federal do Paraná - HCUFPR) - Curitiba (PR), Brazil.

Resident of Hematology, Teaching Hospital - Federal University of Paraná (Universidade Federal do Paraná - HC-UFPR) - Curitiba (PR), Brazil.

Resident at the School of Medicine of Ribeirão Preto, University of São Paulo (Faculdade de Medicina de Ribeirão Preto - Universidade de São Paulo - FMRPUSP) - Ribeirão Preto (SP), Brazil.

Resident of Pathology at the Teaching Hospital - Federal University of Paraná (Universidade Federal do Paraná - HC-UFPR) - Curitiba (PR), Brazil. 
plaques occurred on the lower limbs, with rapid growth and proximal progression.

The patient reported a recent trip to the coastal area of the State of Paraná, one day before the admission. Samples for leptospirosis, dengue, yellow fever, spotted fever and meningococcemia were collected and were found to be negative.

The patient became unresponsive to volume, had dyspnea and respiratory distress. He was transferred to the ICU and needed vasoactive drugs and mechanical ventilation. His clinical condition progressively worsened associated with increased need for vasoactive drugs. The skin lesions became confluent, forming blisters, and there was discharge of sero-sanguineous fluids (Figure 1). Therapy with ceftriaxone was changed to meropenem and oxacillin. Blood cultures revealed growth of a gram-negative bacillus, which was later identified as Vibrio vulnificus. Approximately 32 hours after the onset of infection, the patient died.

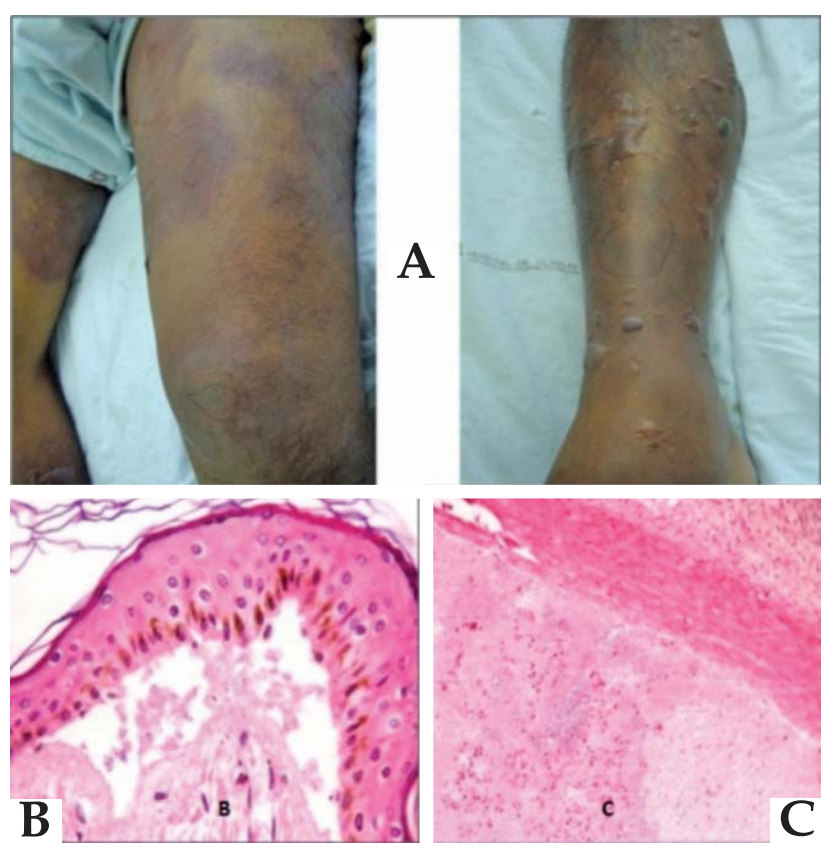

Figure 1: (A) Pictures of skin lesions, multiple tense bullae and intense edema, with about twelve hours of evolution. Histopathological findings from leg and spleen. (B) Presence of gram-negative bacilli in the subepidermal space. (C) Presence of gram-negative bacilli inside the splenic small vessels. (H\&E, 400X)

\section{DISCUSSION}

Vibrio vulnificus is a gram-negative bacillus, which lives in warm coastal areas with salt in the intermediate layer, as in the Gulf of Mexico, colonizing marine wildlife, especially during the summer. In that area, studies have reported that practically $100 \%$ of oysters were colonized by $V$. vulnificus and/or $V$. parahaemolyticus. ${ }^{3,45,6}$ Primary infection by $V$. vulnificus occurs through ingestion of the microorganism in contaminated food and subsequent bacterial translocation across the gastrointestinal mucosa. The initial symptoms are abdominal pain, nausea, myalgia and fever. The development of sepsis is very fast, in average 18 hours after ingestion, and is usually accompanied by the emergence of bullous skin lesions especially on the extremities, as well as the occurrence of disseminated intravascular coagulation. ${ }^{4}$ In cases of sepsis, mortality is higher than $50 \%,{ }^{4,7}$ reaching $90 \%$ in cases where septic shock occurs less than twelve hours after the onset of symptoms. ${ }^{5}$

Besides the skin lesions that occur in sepsis, the epidermis may be affected by direct infection through skin lesions that look like bullous cellulitis. At first, there is pain and swelling in the affected limb, followed by rash, and then the emergence of bullous lesions with sero-hemorrhagic fluids, progressing to necrotizing fasciitis ${ }^{4}$, similar to that caused by other agents transmitted by water exposure, as Aeromonas hydrophila. ${ }^{3,4}$

The definitive diagnosis of infection by $V$. vulnificus occurs through the growth of microorganism cultures. Laboratory tests of the patients change, indicating severe sepsis, often with leukocytosis and a major shift to the left as well as alteration in renal function. ${ }^{8}$ On the other hand, the imaging tests showed non-specific changes such as edema and accumulation of fluid in the affected tissues.

A factor of great importance regarding infection by $V$. vulnificus is the increased susceptibility in individuals with immunodeficiencies, liver disease and diseases of iron accumulation, in which the presence of high iron load in the bloodstream, as evidenced by elevated levels of ferritin and transferrin saturation in the blood, seems to increase the virulence of the bacillus., ${ }^{3,9}$ Other risk factors for infection are diabetes mellitus, use of steroids and chronic renal failure.

Due to the severity of infections by $V$. vulnificus, early diagnosis and therapy are essential. The 24-hour delay in treating patients with sepsis leads to increased mortality, ranging from 33 to $53 \%$ and reaching $100 \%$ in patients who are treated only 72 hours after the infection onset. ${ }^{10}$, A high index of suspicion is necessary for appropriate treatments, as doxycycline, the antibiotic of choice, is not usually a part of the empiric therapy for septicemia. The risks of eating raw seafood should always be considered to reduce the threat of outbreak of this infection in exposed people. ${ }^{1}$

Prophylactic measures are of great importance for patients more susceptible to infection. The ingestion of seafood should be avoided, and only well- 
cooked seafood should be eaten. Also, contact of open wounds with seawater should be avoided, especially in areas of greater risk (high and intermediate water salinity under heat) and in the summer. ${ }^{3}$

In this case, the patient died in the first 30 hours of hospitalization and the culture result was available three days post-mortem. Similar to previous reports, 24 hours after raw fish ingestion the patient presented a clinical outcome of septicemia and refractory septic shock, which despite the intensive care unit support and antibiotic therapy quickly resulted in death, emphasizing the severity of this infection.
This is the first report of $V$. vulnificus-induced illness in Southern Brazil, where water temperature is generally lower than in the rest of the Brazilian coast. However, higher temperatures have been detected in this region, probably as a consequence of global climate change. The high mortality associated with this septicemia demands aggressive preventive measures, such as microbial surveillance and warning to consumers. Clinicians managing patients with chronic liver disease and other immunocompromised disease need to educate their patients about the risk associated with the consumption of raw seafood. ${ }^{1}$

\section{REFERENCES}

1. Haq SM, Dayal HH. Chronic liver disease and consumption of raw oysters: a potentially lethal combination--a review of Vibrio vulnificus septicemia. Am J Gastroenterol. 2005;100:1195-9

2. Bross MH, Soch K, Morales R, Mitchell RB. Vibrio vulnificus Infection: Diagnosis and Treatment. Am Fam Physician. 2007;76:539-44.

3. Jones MK, Oliver JD. Vibrio vulnificus: disease and pathogenesis. Infect Immunity. 2009; 77:1723-33.

4. Ulusarac 0, Carter E, Oliver JD. Varied clinical presentantions of vibrio vulnificus infections: a report of four unusual cases and review of the literature. South Med J. 2004;97:163-8.

5. Morris JG Jr. Cholera and other types of vibriosis: A story of human pandemics and oysters on the half shell. Clin Infect Dis. 2003;37:272-80.

6. Morris JG. "Non-cholera" Vibrio species. In: Blaser MJ, Smith PD, Ravdin JI, Greenberg HB, Guerrant RL, editors. Infections of the Gastrointestinal Tract. 2nd ed. Philadelphia: Lippincott, Williams \& Wilkins; 2002. p.167-9.

7. Hlady WG, Klontz KC. The epidemiology of vibrio infections in Florida, 1981-1993. J Infect Dis. 1996;173:1176-83.

8. Lerstloompleephunt N, Tantawichen T, Sitprija V. Renal failure in vibrio vulnificus infection. Ren Fail. 2000;22:337-43.
9. Hor LI, Chang TT, Wang ST. Survival of Vibrio vulnificus in whole blood from patients with chronic liver diseases: association with phagocytosis by neutrophils and serum ferritin levels. J Infect Dis. 1999;179:275-8.

10. Bilton BD, Zibari GB, McMillan RW, Aultman DF, Dunn G, McDonald JC. Aggressive surgical management of necrotizing fasciitis serves to decrease mortality: a retrospective study. Am Surg. 1998;64:397-400.

\footnotetext{
MAILING ADDRESS:

João César Beenke França

Serviço de Infectologia. Hospital de Clínicas da UFPR.

Rua General Carneiro, 181 - $3^{\circ}$ andar

80.060-900 - Curitiba - PR

Brazil

E-mail: jofranbk@yahoo.com.br
}

How to cite this article: França JC, Raboni SM, Sanfelice E, Polido D, Gentili A, Marques F. Vibrio vulnificus infection in Southern Brazil: a case report. An Bras Dermatol. 2013;88(3):424-6. 